\title{
MAPPING STOCK AT RISK AND RELEASE OF ZINC AND COPPER IN SWITZERLAND - DOSE RESPONSE FUNCTIONS FOR RUNOFF RATES DERIVED FROM CORROSION RATE DATA
}

\author{
D. REISS ${ }^{1, *}$, B. RIHM ${ }^{2}$, C. THÖNI ${ }^{2}$ and M. FALLER ${ }^{1}$ \\ ${ }^{1}$ Swiss Federal Laboratories for Materials Testing and Research (EMPA), Überlandstr: 129, \\ CH-8600 Dïbendorf, Switzerland; ${ }^{2}$ Meteotest, Fabrikstrasse 14, CH-3012 Bern, Switzerland \\ (*author for correspondence, e-mail: daniel.reiss@empa.ch, \\ Fax: +4118234015 , Tel: +4118234775 )
}

(Received 4 September 2003; accepted 9 May 2004)

\begin{abstract}
Copper and zinc are the most abundant facade and roofing materials sensitive for corrosion in Switzerland. For calculating potential material losses of copper and zinc by corrosion-induced runoff, i.e. washed or blown away material, dose-response functions (DRFs) are derived from the results of a Swiss outdoor corrosion exposure programme (Leuenberger-Minger et al., 2002b, Mater: Corros. 53, 157-164). The DRFs are also compared with other DRFs available from literature.

Based on these DRFs, calculated runoff rates of $\mathrm{Cu}$ and $\mathrm{Zn}$ are mapped for Switzerland on a $250 \times 250 \mathrm{~m}$ raster. The required input maps (climate and pollution levels) are produced by spatial interpolation of monitoring data from over 60 stations. The stock at risk of zinc and copper which are exposed in open atmosphere is calculated by two methods: (1) The bottom-up method uses data which were evaluated in a representative region in Switzerland by estimating the installed metallic roof and facade materials in the field. These data are projected to the total area of Switzerland on the basis of a land-use map. (2) The top-down method uses statistical data of imported zinc and copper material. The amount and surface of material that is used under outdoor conditions are calculated by use of different assumptions.

The maps of runoff rates and stock at risk are then overlaid for calculating the annual flux of released metals. While the economic aspect of corrosion is presumably less important, the ecological risk of the runoff of metals should be considered in future research and mapping activities.
\end{abstract}

Keywords: air pollution, atmospheric corrosion, copper and zinc dispersion, GIS, metal release, regression analysis, runoff

\section{Introduction}

Adverse effects of air pollution on materials exposed to the atmosphere have been investigated for several years under the UN ECE Convention on Long-Range Transboundary Air Pollution. Based on exposure experiments throughout Europe, quantitative dose-response functions (DRFs) were developed, which allow the corrosion and deterioration rates to be calculated for different materials, depending on concentrations of air pollutants and climatic parameters (Tidblad et al., 1999). These "unified" corrosion DRFs that were compiled within the UN ECE can be used for mapping and for calculation of costs in different climatic regions.

In Switzerland, a 4-year exposure programme was run at 8 sites from 1993 to 1996 (Leuenberger-Minger et al., 2002a). The exposed materials were weathering 
TABLE I

Dose-response functions for metal release of copper and zinc

\begin{tabular}{lllr}
\hline Material & Equation & $\begin{array}{l}\text { Ratio } \\
\mathrm{Sp} / \mathrm{Se}\end{array}$ & $R^{2}$ \\
\hline Zinc, $F 1$ & $M R_{\mathrm{Zn}}=0.07 \cdot \mathrm{SO}_{2}^{1.5} t^{1.1}+0.0014 \mathrm{Rain} \cdot t+0.04 \cdot \mathrm{O}_{3}^{0.23} \cdot \mathrm{Temp}^{1.4} \cdot t^{0.4}$ & 1.0 & 0.84 \\
Zinc, $F 2$ & $M R_{\mathrm{Zn}}=\left(1.36+0.16 \cdot \mathrm{SO}_{2}\right) \cdot t$ & 0.58 & 0.80 \\
Zinc, $F 3$ & $M R_{\mathrm{Zn}}=0.53 \cdot \mathrm{SO}_{2}^{0.22} \cdot$ Exp $(0.018 \cdot \mathrm{Rh}+F \cdot[\mathrm{Temp}]) \cdot t^{0.85}+1.05 \cdot \mathrm{Rain} \cdot\left[\mathrm{H}^{+}\right] \cdot t$ & 1.0 & 0.69 \\
& $\quad$ Modified "unified" corrosion DRF for unsheltered zinc. & 1.0 & 0.92 \\
Copper & $M R_{\mathrm{Cu}}=0.0034 \mathrm{SO}_{2} \mathrm{O}_{3} t+0.00035 \mathrm{Rain} t$ & 1.0 & \\
\hline
\end{tabular}

Note. F1, specific DRF for Switzerland (Rihm et al., 2003); F2, runoff DRF (Odnevall Wallinder et al., 1998) multiplied with $t$; F3, modified; "UN/ECE" corrosion DRF based on (Tidblad et al., 1999 see section 2.2); $M R$, metal release [ $\left.\mathrm{g} / \mathrm{m}^{2}\right]$; division by $t$ gives annual runoff rates; $t$, exposure duration [years]; $\mathrm{SO}_{2}$, concentration of sulphur dioxide, (annual) mean $\left[\mu \mathrm{g} / \mathrm{m}^{3}\right] ; \mathrm{O}_{3}$, concentration of ozone, (annual) mean $\left[\mu \mathrm{g} / \mathrm{m}^{3}\right]$, Rh, relative humidity, (annual) mean [\%]; Rain, rain amount, (annual) mean $[\mathrm{mm} /$ year $] ;\left[\mathrm{H}^{+}\right], \mathrm{H}^{+}$concentration $[\mathrm{mg} / \mathrm{l}]$ in rain derived from $\mathrm{pH}$, for Switzerland an average of $0.00133 \mathrm{mg} / \mathrm{l}$ was used; Temp, Temperature $\left[{ }^{\circ} \mathrm{C}\right] ; F$ [Temp], Function of Temp: If Temp $>10^{\circ} \mathrm{C}, \mathrm{F}=-$ 0.021 (Temp -10) otherwise $F=0.062$ (Temp-10). For the stock at risk assessment it is also important to know the ratio between the sum of the DRF-predicted runoff ( $\mathrm{Sp}$ ) and the sum of the experimentally derived runoff (Se).

steel (WTSt 52), copper and zinc. From the measured corrosion data the runoff rate was calculated by comparing the metal content in the remaining corrosion products and totally corroded metal (see Section 2.1). For zinc, the specific DRFs for Switzerland were compared with a runoff DRF (Odnevall Wallinder et al., 1998) and a modified "UN ECE" corrosion DRF (Table I).

In order to quantify overall metal release due to atmospheric corrosion in Switzerland, first mapping activities were started in 2000 (Rihm et al., 2000). This paper presents maps of potential runoff rates based on the Swiss DRFs as well as improved maps of the stock at risk. The following input maps were required: $\mathrm{SO}_{2}$ concentration, $\mathrm{O}_{3}$ concentration, relative humidity $(\mathrm{Rh})$, temperature (Temp), rain amount and for the "UN ECE" DRF an average of $\mathrm{H}^{+}$concentration for Switzerland.

\section{Methods and Data}

\subsection{SAMPLING}

The samples were exposed facing south, with a surface inclination of $45^{\circ}$ to the horizon. After exposure to the atmosphere, the corrosion products on the surface of the exposed metal samples were removed using pickling solutions. The mass of corrosion products retained on the surface and material loss were determined by weighing the test specimens before exposure, after exposure and after removal of the corrosion products. (Faller, 2003; Leuenberger-Minger et al, 2002b; see 
Section 3.1). To estimate the effective runoff of metallic material to the environment the runoff was calculated by comparing the metal proportion in the held-back corrosion products and the total corrosion loss. The corrosion products were identified as mainly cuprite $\left(\mathrm{Cu}_{2} \mathrm{O}\right)$ and small amounts of posnjakite $\left(\mathrm{Cu}_{4} \mathrm{SO}_{4}(\mathrm{OH})_{6} \cdot 2 \mathrm{H}_{2} \mathrm{O}\right)$ for copper and for zinc mainly as hydrozincite $\mathrm{Zn}_{5}\left(\mathrm{CO}_{3}\right)_{2}(\mathrm{OH})_{6}$. It has to be noted that in order to calculate the runoff it was assumed that the corrosion products consist only of the predominating cuprite for copper and hydrozincite for zinc respectively (see Section 3).

\subsection{DOSE-RESPONSE FUNCTIONS}

Swiss DRFs, which were chosen for mapping, are shown in Table I (Rihm et al., 2003). Because of the strong correlation with ozone, $\mathrm{NO}_{2}$ concentrations were excluded from the statistical analysis. In order to interpolate $\mathrm{O}_{3}$ concentrations a $\mathrm{NO}_{2}$ map was used (Table II).

To modify the "UN ECE" corrosion function into a runoff function the coefficients of the two additive terms were calculated with a multiple linear regression with two boundary conditions: (1) The sum of the predicted runoff by the DRF $(\mathrm{Sp})$ and the sum of all runoff values derived from corrosion data $(\mathrm{Se})$ should

\section{TABLE II}

Overview of the interpolation methods used to map the input parameters that are required in the dose-response functions

\begin{tabular}{|c|c|c|c|}
\hline Parameter & Regression equations, remarks & Stations & $R^{2}$ \\
\hline \multirow[t]{2}{*}{$\mathrm{SO}_{2}$} & $\begin{array}{l}\text { Values for } 1995, \text { north of the alps: } \\
\qquad 4.64-0.00139 \cdot z+0.0952 \cdot(3 \cdot i g 8+w g 8)\end{array}$ & 65 & 0.80 \\
\hline & $\begin{array}{l}\text { Mean values for } 1993-98 \text {, south of the alps (Barbieri and Pozzi, } \\
2001): 0.07 \cdot(3 \cdot \operatorname{ig} 8+w g 8)+18.2 \cdot \mathrm{e}^{-2.3 \cdot z}\end{array}$ & 8 & 0.95 \\
\hline \multirow[t]{2}{*}{$\mathrm{O}_{3}$} & $\begin{array}{l}\text { Mean values } 1996-1999 . \text { North of the alps: } \\
66.6-0.0307 \cdot y+0.0301 \cdot \mathrm{zrel}-0.552 \cdot \mathrm{NO}_{2}\end{array}$ & 72 & 0.82 \\
\hline & South of the alps: $61.9-0.0149 \cdot z+1.55 \cdot \mathrm{zrel}^{0.5}-0.66 \cdot \mathrm{NO}_{2}$ & 22 & 0.84 \\
\hline Temp & $\begin{array}{l}\text { Mean values 1983-1992. Function of altitude for } 11 \text { different } \\
\text { regions. }\end{array}$ & 59 & - \\
\hline $\mathrm{Rh}$ & $\begin{array}{l}\text { Mean values 1983-1992. Altitude correction, anisotrophe } \\
\text { 2D-kriging. Local topographic corrections: depressions, } \\
\text { south-facing slopes. } 250 \text {-m grid. }\end{array}$ & 59 & - \\
\hline Rain & Geostatistical interpolation, data (FOWG, 2000) & 290 & - \\
\hline
\end{tabular}

Nore. y, Latitude, national projection system [km], interval $70-300 \mathrm{~km} ; z$, Altitude above sea level [m], $250 \mathrm{~m}$ grid; $z$ rel, Relative altitude, defined as altitude minus the lowest altitude occurring within a distance of $5 \mathrm{~km}[\mathrm{~m}], 250 \mathrm{~m}$ grid; $\mathrm{NO}_{2}$, Annual mean $\mathrm{NO}_{2}$ concentration $\left[\mu \mathrm{g} / \mathrm{m}^{3}\right]$. Output from dispersion model based on $200 \mathrm{~m}$ emission inventory grid (BUWAL, 1996); wg8, Area of houses [ha] within a radius of $800 \mathrm{~m}$, derived from LU-data; ig 8 , Area of industrial buildings [ha] within a radius of $800 \mathrm{~m}$, derived from LU-data; LU, Land use, 79 categories, 100-m grid (BFS, 1992). 
be the same for each exposure site individually and (2) for all measured values together:

For the stock at risk assessment besides a high coefficient of determination $\left(R^{2}\right)$ it is also important to know the ratio $\mathrm{Sp} / \mathrm{Se}$ for each DRF to distinguish between under- $(\mathrm{Sp} / \mathrm{Se}<1)$ and over-estimation $(\mathrm{Sp} / \mathrm{Se}>1)$, see Table I. The total metal flux to the environment for all test sites during the exposure program and averaged climatic parameters are shown in Table VI.

\subsection{INPUT MAPS}

The required input maps are produced by spatially interpolating the values from monitoring stations. The interpolation methods are similar for $\mathrm{SO}_{2}$ and $\mathrm{O}_{3}$ : (1) A multiple linear regression analysis is made. The input parameters must be available in the form of digital maps for the whole country at the required spatial resolution. For $\mathrm{O}_{3}$ and $\mathrm{SO}_{2}$ it was necessary to form three sub-regions: north of the Alps, south of the Alps and large inner-alpine valleys. (2) The equations found in the regression analysis are applied on a cell-by-cell basis to calculate the "trend map" of the parameter we are looking for. (3) If the quality and spatial distribution of the monitoring stations are adequate, the residuals (measured minus calculated value) are interpolated between the monitoring stations by inversedistance-weighting. This "residual map" can then be used to correct the trend map. Thus, the final input maps reproduce the exact measured values at the monitoring stations.

The interpolation methods for $\mathrm{Rh}$ and Temp can be summarised as follows: (1) The measured values are corrected for the influence of altitude by a linear regression. (2) The coordinate system is transformed in such a way that distances parallel to the chain of the Alps are shortened by a factor of 0.8 (climatic anisotrophy). (3) The values are interpolated by horizontal kriging. (4) The coordinate system and altitude function is transformed back. (5) Local corrections are applied.

Table II gives an overview of the interpolation methods that were used to produce the input maps. In general, the calculations are made on a $250 \times 250 \mathrm{~m}$ grid. The most important input data are available at this resolution, i.e. topography, $\mathrm{NO}_{2}$ and land use.

\subsection{STOCK AT RISK}

The stock at risk of zinc and copper that are exposed in open atmosphere is calculated by two methods. (1) The bottom-up method uses data that were evaluated in a representative region in Switzerland by estimating the installed materials in the field. These data are projected to the total area of Switzerland. (2) The top-down method uses statistical data of imported zinc and copper material. The amount and surface of material that is used under outdoor conditions are calculated by use of different assumptions. 
TABLE III

Average surface of copper per hectare of land use types in built-up areas of the Tösstal catchment in 1997

\begin{tabular}{lcc}
\hline Building types (incl. surroundings) & Built-up land cover & Copper surface $\left(\mathrm{m}^{2} / \mathrm{ha}\right)$ \\
\hline Industrial buildings & $12 \%$ & 35 \\
l- and 2-storey houses & $26 \%$ & 135 \\
Housing blocks ( $>2$ storeys) & $8 \%$ & 245 \\
Agricultural buildings & $12 \%$ & 15 \\
Mixed-use buildings, construction sites & $42 \%$ & 145 \\
\hline
\end{tabular}

Source: Singeisen and Boller, 1997, modified.

The first regional study focused mainly on copper on buildings and was carried out in the Tösstal catchment area (Singeisen and Boller, 1997). They examined the area of metal parts for five different types of buildings, which were defined according to land use data with 79 categories available for the whole country with a resolution of $100 \mathrm{~m}$ (BFS, 1992). The average amounts of copper are shown in Table III, expressed in $\mathrm{m}^{2}$ of metal per hectare of buildings (including surroundings). The average copper cover was $5 \%$ of the roof surface. These results can be bottom-up extrapolated according to the land use pattern in 1985, resulting in $17 \mathrm{~km}^{2}$ of copper for the whole area of Switzerland. Taking into consideration the development of the built-up area in Switzerland from 1985 to 2000, a total copper surface of more than $22 \mathrm{~km}^{2}$ can be expected. For runoff calculation an average inclination of $45^{\circ}$ was derived because of the approximatively circular roof and gutter geometry, which is the most applied form in Switzerland (for an individual building the actual inclination has to be taken into account).

A second bottom-up study for zinc and other metals is available from Stolz et al. (1994). They surveyed larger objects such as tank farms, bridges, railways and main roads in three cantons (covering $25 \%$ of total area of Switzerland). They found the largest part of zinc surfaces on guard rails and power transmission lines. Contact lines for railway systems were less important. A projection of the amount of revealed objects onto the whole country resulted a zinc surface of $10 \mathrm{~km}^{2}$. The authors also calculated a top-down approach resulting in an unsheltered zinc surface of $47 \mathrm{~km}^{2}$, assuming a total stock of galvanised steel of $200 \mathrm{kt} \mathrm{Zn,} \mathrm{33 \%} \mathrm{unsheltered,}$ $50 \%$ of the unsheltered objects protected by duplex coatings and a mean thickness of the $\mathrm{Zn}$-layer of $0.1 \mathrm{~mm}$. They concluded that the large number of smaller objects not considered in their field survey (e.g. candelabra, traffic signs, fences) are important.

A follow-up study by Stolz (2001) shows a more detailed top-down calculation for galvanised objects and the use of zinc dust, which is summarised in Table IV. It also gives national estimates for guard rails $\left(7 \mathrm{~km}^{2}\right)$, power transmission pylons $\left(5 \mathrm{~km}^{2}\right)$, candelabra/traffic signs $\left(3 \mathrm{~km}^{2}\right)$ and pylons of contact lines $\left(1.5 \mathrm{~km}^{2}\right)$. 
Information on titanium zinc as well as copper used for roofs and facades was compiled by (KBOB, 2001) and is included also in Table IV. RHEINZINK Switzerland Baden-Dättwil (personal communication April 2000) gives in accordance with KBOB (2001) the following numbers: From 1995 to 1999 the mean annual consumption of titanium-zinc was 4875 tons (90\% was used on roofs, $10 \%$ on facades), the consumption of copper was 12810 tons per year. This means the actual consumption is considerably higher than the assumed mean consumption during the last decades given in Table IV.

\section{TABLE IV}

Stock at risk for Zinc and Copper in the year 2000

\begin{tabular}{llllll}
\hline Material, main use & $\begin{array}{l}\text { Annual } \\
\text { consumption }(t / \text { year })\end{array}$ & $\begin{array}{l}\text { Life-span } \\
\text { (years) }\end{array}$ & $\begin{array}{l}\text { unsheltered } \\
\%\end{array}$ & $\begin{array}{l}\text { Thickness } \\
(\mathrm{mm})\end{array}$ & $\begin{array}{l}\text { Total metal } \\
\text { surface }\left(\mathrm{km}^{2}\right)\end{array}$ \\
\hline $\begin{array}{c}\text { Copper: roofs, drains, } \\
\text { gutters, facades }\end{array}$ & 7000 & 50 & 50 & 0.8 & $25(20-35)$ \\
$\begin{array}{c}\text { Titanium-zinc: roofs, } \\
\text { facades }\end{array}$ & 3375 & 50 & 30 & 0.7 & 10 \\
$\begin{array}{c}\text { Zinced/galvanised } \\
\text { steel: broadly used } \\
\text { for large and small } \\
\text { objects }\end{array}$ & 1670 & 30 & 30 & 0.1 & 21 \\
$\begin{array}{l}\text { Zinc dust: bridges, } \\
\text { tank farms }\end{array}$ & 340 & 50 & 80 & 0.25 & 8 \\
\begin{tabular}{c} 
Total zinc \\
\hline
\end{tabular} & & & & $39(30-60)$ \\
\hline
\end{tabular}

Source: Assumptions and top-down calculations based on KBOB (2001) and Stolz (2001).

aMean value 1970-2000 or 1950-2000 according to lifespan.

TABLE V

Spatial distribution of unsheltered copper and zinc according to (aggregated) land use categories per hectare

\begin{tabular}{lcc}
\hline Categories of land use & $\mathrm{Cu}(\%)$ & Zn (\%) \\
\hline Industrial buildings and surroundings & 6 & 28 \\
One-/two-family houses and surroundings & 24 & 18 \\
Blocks of flats (>2 storeys) and surroundings & 42 & 5 \\
Agricultural buildings and surroundings & 3 & 2 \\
Unspecified buildings and surroundings; construction sites & 25 & 17 \\
Streets, lanes and parking sites (incl. green environs) & 0 & 14 \\
Motorway (incl. green environs) & 0 & 10 \\
Railway (incl. green environs) & 0 & 2 \\
Supply and waste treatment plants & 0 & 4 \\
Total & 100 & 100 \\
\hline
\end{tabular}

Source: BFS (1992). 
Most of the input parameters have an uncertainty of approximately $30 \%$. The range of the resulting metal surfaces is quite large. For the mapping exercise, a copper surface of $25 \mathrm{~km}^{2}$ is used as the most probable value, which is in good accordance with top-down and bottom-up results. For zinc, a value of $39 \mathrm{~km}^{2}$ is used for mapping. Table $\mathrm{V}$ indicates, how the total metal surfaces are spatially allocated in the mapping procedure.

The resulting maps of stock at risk can be combined with the runoff rates in order to create a map of the annual metal release for copper and zinc in Switzerland.

\section{Results}

\subsection{COPPER: ACCUMUlated RUNOFF AND RUNOFF RATE}

After 4 years of exposure, accumulated runoff was found to be between 1.7 and $6.9 \mathrm{~g} / \mathrm{m}^{2}$ (Table VI). These amounts correspond to about $15 \%$ of the total amount of corrosion products. Odnevall Wallinder and Leygraf (1997) found percentages of 15 and $22 \%$ for 1 and 2 years of exposure respectively. The left over corrosion products are held back on the metal plate and form the protective layer called patina. Runoff rates reach a relatively stable value after 1 year of exposure. After 4 years of exposure the annual runoff rate is between 0.46 and $1.7 \mathrm{~g} /\left(\mathrm{m}^{2} \cdot\right.$ year) (calculated from Table VI). The lowest value was found for the least polluted site Davos, the values of runoff rates for the more polluted sites such as Cadenazzo being 3.8 times higher and for Härkingen being 2.6 times higher. For the test sites that are situated

\section{TABLE VI}

Accumulated runoff (calculated) of corroded copper and zinc into the environment after $0.5,1,2$ and 4 years exposure, in $\mathrm{g} / \mathrm{m}^{2} \mathrm{Cu}$ or $\mathrm{Zn}$ of exposed material

\begin{tabular}{|c|c|c|c|c|c|c|c|c|c|c|c|c|}
\hline & \multicolumn{4}{|c|}{$\mathrm{Cu}\left(\mathrm{g} / \mathrm{m}^{2}\right)$} & \multicolumn{4}{|c|}{$\mathrm{Zn}\left(\mathrm{g} / \mathrm{m}^{2}\right)$} & \multicolumn{4}{|c|}{ Climate averages } \\
\hline & 0.5 & 1 & 2 & 4 & 0.5 & 1 & 2 & 4 & $\begin{array}{l}\mathrm{SO}_{2}(4 \mathrm{y}) \\
\left(\mu \mathrm{g} / \mathrm{m}^{3}\right)\end{array}$ & $\begin{array}{l}\mathrm{O}_{3}(4 \mathrm{y}) \\
\left(\mu \mathrm{g} / \mathrm{m}^{3}\right)\end{array}$ & $\begin{array}{l}\operatorname{rain}(1 \mathrm{y}) \\
(\mathrm{m} / \mathrm{a})\end{array}$ & $\begin{array}{l}\operatorname{rain}(4 y) \\
(\mathrm{m} / \mathrm{a})\end{array}$ \\
\hline Dübendorf & 0.39 & 1.4 & 2.6 & 4.7 & 2.2 & 4.3 & 7.1 & 12 & 6.8 & 36 & 1.1 & 1.0 \\
\hline Lägern & 0.47 & 1.1 & 1.7 & 3.7 & 1.7 & 3.5 & 5.8 & 11 & 2.9 & 60 & 0.95 & 1.0 \\
\hline Härkingen & $<0.10$ & 0.11 & 1.1 & 4.7 & 3.3 & 7.1 & 14. & 24 & 8.3 & 26 & 1.1 & 0.83 \\
\hline Bern & 0.21 & 0.35 & 1.6 & 3.0 & 1.5 & 3.3 & 6.1 & 10 & 7.0 & 11 & 1.1 & 1.1 \\
\hline Payerne & 0.28 & 0.58 & 2.2 & 2.7 & 1.9 & 3.9 & 6.8 & 11 & 2.3 & 48 & 0.97 & 0.91 \\
\hline Sion & $<0.10$ & 0.33 & 2.1 & 2.5 & 2.6 & 4.8 & 7.9 & 11 & 3.5 & 33 & 0.67 & 0.66 \\
\hline Cadenazzo & $<0.10$ & 1.6 & 3.8 & 6.9 & 3.1 & 7.4 & 13 & 22 & 7.8 & 42 & 1.9 & 1.6 \\
\hline Davos & $<0.10$ & $<0.10$ & 1.4 & 1.7 & 1.4 & 2.2 & $5.0^{\prime}$ & 7.9 & 1.3 & 68 & 1.2 & 1.1 \\
\hline
\end{tabular}

Note. The climatic parameters were averaged for the respective test periods (LeuenbergerMinger et al., 2002b). 
in the more populated region of Switzerland, the annual runoff rate lies between 0.8 and $1.8 \mathrm{~g} /\left(\mathrm{m}^{2} \cdot\right.$ year $)$.

The copper DRF predicts $81 \%$ of the runoff rates within $33 \%$ from the reported values in Table VI (without values below $0.4 \mathrm{~g} / \mathrm{m}^{2}$ ).

\subsection{ZINC: ACCUMULATED RUNOFF AND RUNOFF RATE}

To estimate the ecological influence of zinc corrosion we need to know the effective runoff of metallic material to the environment and the chemical speciation. Because of the calculation of the runoff rates from corrosion rates only the total mass loss as first step is available. After 4 years of exposure, an amount of 7.9 to $24 \mathrm{~g} / \mathrm{m}^{2}$ of zinc metal is washed away into the environment (Table VI). These amounts correspond to about $60 \%$ of the total amount of corrosion products. Verbiest (Verbiest et al., 1997) found percentages of $53-68 \%$ for 2 years and $60-80 \%$ for 4.5 years of exposure. The left over corrosion products are held back on the metal plate. The runoff of metallic material was calculated in the same way as it was done for copper (see Section 2.1).

Runoff rates of the investigated glass blasted zinc still decreases after 2 years of exposure. After 4 years of exposure the annual runoff rate was between 2.0 and $6.0 \mathrm{~g} /\left(\mathrm{m}^{2}\right.$ year) (calculated from Table VI). The lowest value was found for the least polluted site Davos, the values for the more polluted sites Cadenazzo and Härkingen being about three times higher. For the test sites that are situated in the more populated region of Switzerland annual runoff rates between 2.9 and $5.7 \mathrm{~g} /\left(\mathrm{m}^{2} \cdot\right.$ year $)$ can be assumed.

The under-estimation of all runoff values $(\mathrm{Sp} / \mathrm{Se}=0.58$, Table I) by the DRF $F 2$ can be explained by the presence of much higher sulfur dioxide concentrations and lower rain amounts at the test sites, reported by Odnevall Wallinder (Odnevall Wallinder et al., 1998). Only $28 \%$ of all predicted values of the function $F 2$ are within $33 \%$ from the runoff rates in Table VI, $81 \%$ and $66 \%$ for $F 1$ and $F 3$, respectively.

\subsection{MAPPING}

The calculated runoff rates are summarized in Table VI and VII. The resulting maps for $\mathrm{Cu}$ and $\mathrm{Zn}$ (Figures 1 and 2) have a cell size of $250 \times 250 \mathrm{~m}$ and cover the whole country. Altitudes above $2000 \mathrm{~m}$ and lakes are excluded (no data). Table VII also shows the calculated runoff rates for the area that is covered by buildings (derived from land use data per hectare). About $1319 \mathrm{~km}^{2}$ or $3.2 \%$ of the area of the Swiss territory is covered by urban areas and settlements; in these areas the mean runoff rate is $1.3 \pm 0.3 \mathrm{~g} /\left(\mathrm{m}^{2} \cdot\right.$ year $)$ for copper and $3.6 \pm 0.9 \mathrm{~g} /\left(\mathrm{m}^{2} \cdot\right.$ year $)$ for zinc.

For estimating the total metal release, the runoff rates, as shown in Figures 1 and 2, have been multiplied on a hectare-by-hectare-basis with the stocks at risk 
TABLE VII

Statistical values of the runoff rate maps

\begin{tabular}{llllll}
\hline \multirow{2}{*}{ Material } & Area & Minimum & Maximum & Mean & $\begin{array}{c}\text { Standard } \\
\text { deviation }\end{array}$ \\
\hline Copper & Whole country & 0.4 & 3.2 & 1.2 & 0.3 \\
Zinc, local DRF F1 & built-up area & 0.4 & 3.2 & 1.3 & 0.3 \\
& Whole country & 1.1 & 9.4 & 3.2 & 0.7 \\
Zinc, DRF F2 & built-up area & 1.3 & 9.4 & 3.6 & 0.9 \\
& Whole country & 1.4 & 4.4 & 1.8 & 0.3 \\
Zinc, “UN/ECE” DRF F3 & built-up area & 1.4 & 4.4 & 2.2 & 0.4 \\
& Whole country & 1.1 & 6.0 & 3.6 & 0.7 \\
& built-up area & 1.5 & 5.8 & 3.9 & 0.5 \\
\hline
\end{tabular}

Note. Units: $\mathrm{g} /\left(\mathrm{m}^{2}\right.$ year $)$, annual mean. Method: dose-response function after 4 years exposure.

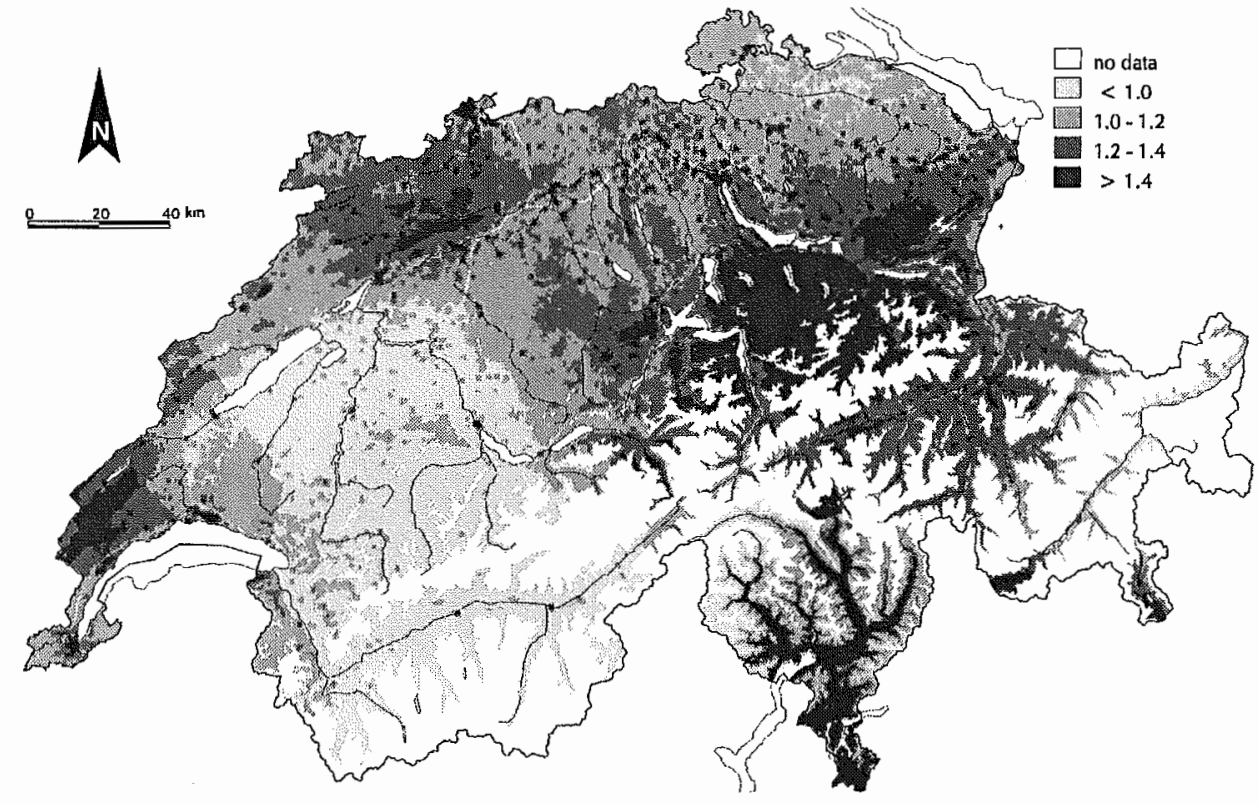

Figure 1. Map of copper runoff rate. (Units: $\mathrm{g} /\left(\mathrm{m}^{2}\right.$ year), annual mean).

for copper and zinc (Figure 3). These results give a total flux of 33 tons of copper and 142 tons of zinc per year in Switzerland.

\section{Discussion}

The DRFs from exposure experiments were implemented in a geographical information system (GIS) on the basis of a $250 \times 250 \mathrm{~m}$ grid. The required input data were already available at this resolution from dispersion models for $\mathrm{NO}_{2}$ and were 


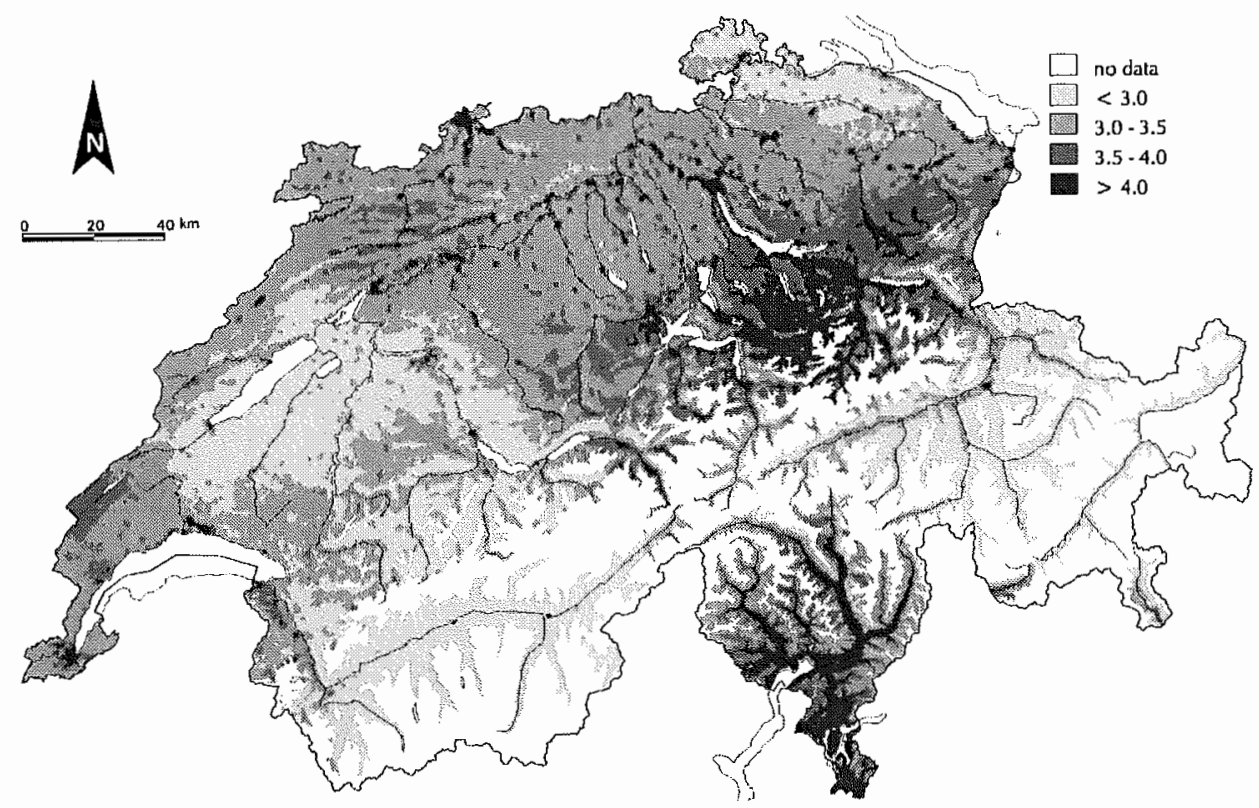

Figure 2. Map of runoff rate for zinc (calculated with Function $F 1$ ). (Units: $g /\left(\mathrm{m}^{2}\right.$ year), annual mean).

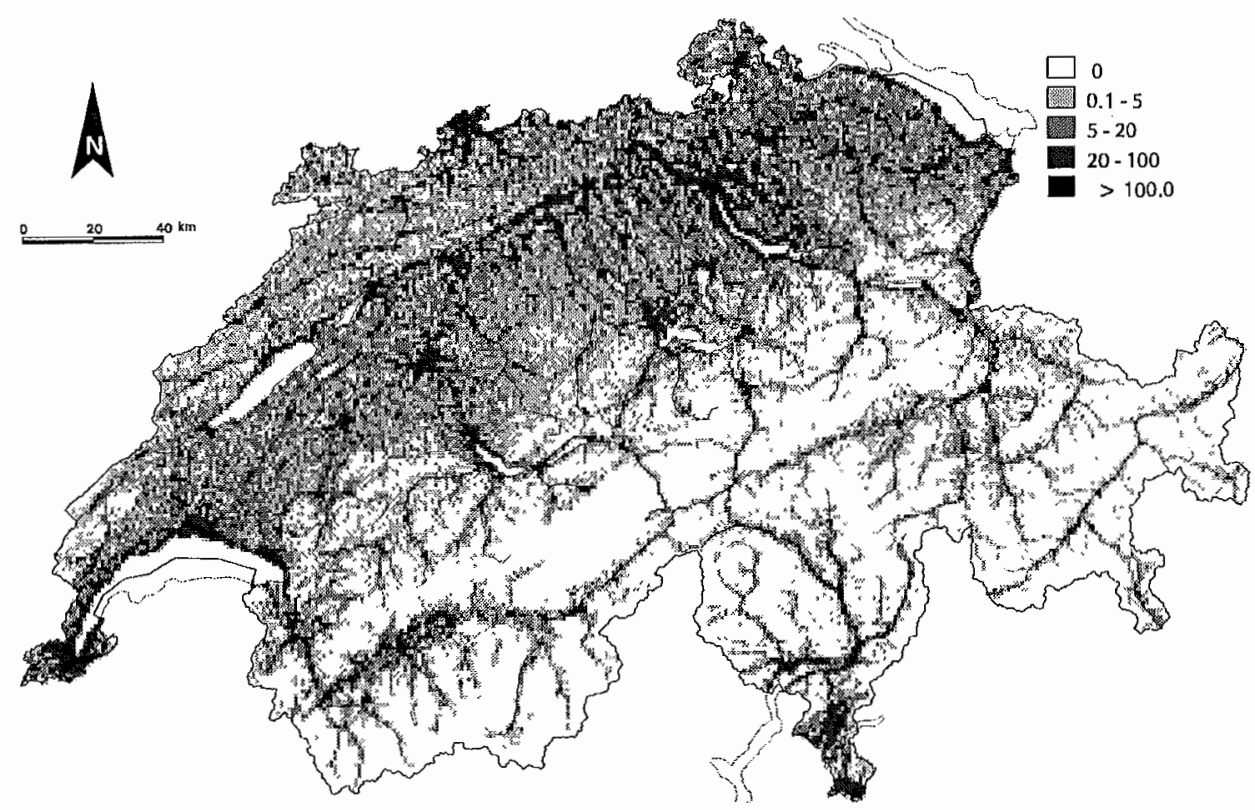

Figure 3. Map of stock at risk of zinc, estimate for the year 2000. [Units: $\mathrm{m}^{2} /$ ha. The total unsheltered surface is $39 \mathrm{~km}^{2}$ for zinc and $25 \mathrm{~km}^{2}$ for copper (map not shown)]. 
interpolated from monitoring stations with empirical geostatistical methods for the other parameters. The spatial resolution of the resulting maps allows urban areas and agglomerations to be distinguished from rural and mountainous areas, with respect to pollution and climate on a regional scale. Peaks in pollution levels due to local emissions cannot be represented.

Mapping was performed with the DRFs for copper and zinc, which have a high correlation coefficient and match the calculated runoff at the measurement sites in a satisfying way. The spatial patterns visible on the maps are strongly influenced by $\mathrm{SO}_{2}$ concentrations and precipitation amounts.

The "local" DRF $F 1$ predicts the observed runoff for Switzerland more accurately than the other DRFs (see Section 3.2). This can be explained by the low sulphur dioxide levels in Switzerland, i.e. other air pollutants like ozone become more important factors for material corrosion.

The resulting runoff rates for copper are practically identical, compared with direct measurements, where the mean runoff caused by atmospheric corrosion is $1.3 \mathrm{~g} /\left(\mathrm{m}^{2} \cdot\right.$ year) (Faller, 2001, 2003), and there is not much difference between glass-blasted and rolled copper samples. For zinc samples the direct measured runoff rate of glass-blasted samples, $3.4 \mathrm{~g} /\left(\mathrm{m}^{2}\right.$.year $)$, used to get the DRFs is in the first years higher than the rate of the rolled samples, $2.6 \mathrm{~g} /\left(\mathrm{m}^{2} \cdot y e a r\right)$, due to the larger surface. In other studies with a yearly quantity of precipitation in the same order of magnitude but with much higher $\mathrm{SO}_{2}$ concentrations at most of the test sites, it was shown that the release of zinc is fairly independent on the type of surface morphology (Odnevall Wallinder et al., 1998). To get more accurate rates, also with respect to the changed $\mathrm{SO}_{2}$ levels, one has to collect all water that runs off the investigated metal surface and measure the amount of metallic ions in the collected water directly.

\section{Outlook}

The release of metals to soils as well as to surface and ground waters is a potential environmental problem. The presented results and maps can be used as a quantitative input to effect-related research projects, e.g. on the basis of specified river catchments. At the moment, DRFs of direct measured runoff are not available, taking into account several climatic parameters; first results of an exposure at sites with similar climate indicate that it is a linear function of time during the first years (Faller, 2001; Odnevall Wallinder et al. (1998)). In the long-term, the corrosion rate will probably reach the runoff rate.

\section{Acknowledgments}

This study is financed by the Swiss Agency for the Environment, Forest and Landscape (National Focal Center for modelling and mapping activities under the 
Convention on Long-range Transboundary Air Pollution). The meteorological data were provided by the Swiss National Pollution Monitoring Network (NABEL) and Meteo Swiss.

\section{References}

Barbieri, A. and Pozzi, S.: 2001, Acidifying Deposition - Southern Switzerland, Swiss Agency for the Environment, Forests and Landscape (SAEFL), Environmental Documentation No. 134, Berne.

BFS: 1992, GEOSTAT Beniitzerhandbuch. Arealstatistik, Hektarraster; Federal Office of Statistics (BFS), Neuchâtel, Switzerland.

BUWAL: 1996, ' $\mathrm{NO}_{2}$-Imissionen in der Schweiz 1990-2010' in Schriftenreihe Umwelt 289, Bundesamt für Umwelt, Wald und Landschaft (BUWAL), Swiss Agency for the Environment, Forests and Landscape (SAEFL). Bern, pp. 57.

Faller, M.: 2001, 'Metallabtrag und Metallabschwemmung von Metalldächern', Baumetall 4, 5259.

Faller, M.: 2003, 'Runoff behaviour of different materials used for roofing and facades - 5 years exposure study in Switzerland', in S. Fitz and V. Kucera (eds), Release of Metals Due to Corrosion of Materials, UN ECE Workshop, Munich, Germany, 12-14, May pp. 3340.

FOWG: 2000, 'Precipitation maps 1961-1999, $2 \times 2 \mathrm{~km}$ resolution, in Hydrological Allas of Switzerland, Federal Office for Water and Geology (FOWG), Berne.

KBOB: 2001, 'Metalle für Dächer und Fassaden', Koordination der Bau- und Liegenschaftsorgane des Bundes (KBOB), Interessengemeinschaft privater professioneller Bauherren (IPB).

Leuenberger-Minger, A.U., Buchmann, B., Faller, M., Richner, P. and Zöbeli, M.: 2002a, 'Doseresponse functions for weathering steel, copper and zinc obtained from a four-year exposure programme in Switzerland', Corrosion Sci. 44, 675-687.

Leuenberger-Minger, A.U., Faller, M. and Richner, P.: 2002b, 'Runoff of copper and zinc caused by atmospheric corrosion', Mater: Corros. 53, 157-164.

Odnevall Wallinder, I. and Leygrat, C.: 1997, 'A study of copper runoff in an urban atmosphere', Corrosion Sci. 39, 2039-2052

Odnevall Wallinder, I., Verbiest, P., He, W. and Leygraf, C.: 1998, 'The influence of patina age and pollutant levels on the runoff rate of zinc from roofing materials', Corrosion Sci. 40, 1977-1982.

Rihm, B., Faller, M. and Leuenberger-Minger, A.U.: 2000, 'Mapping corrosion rates for Switzerland', in V. Kucera and H.-D. Gregor (eds), UN/ECE Workshop, Mapping Air Pollution Effects on Materials Including Stock at Risk, Stockholm, Sweden, 14-16 June, pp. 4148.

Rihm, B., Reiss, D., Thöni, C. and Faller, M.: 2003, 'Dose Response Functions for Runoff Derived from Corrosion Data - Mapping Stock at Risk and Release of Zinc and Copper in Switzerland', in S. Fitz and V. Kucera (eds), Release of Metals Due to Corrosion of Materials, UN ECE Workshop, Munich, Germany, 12-14, May, pp. 145-156.

Singeisen, C. W. and Boller, M.: 1997, 'Dachabfluss als Quelle diffuser Kupferbelastungen, Bilanzierung der Kupferfracht im Dachwasserabfluss über das Einzugsgebiet der Töss', Swiss Federal Institute for Environmentals Science and Technology (EAWAG), Dübendorf', Switzerland, $1-24$.

Stolz, J.: 2001, 'Luftschadstoff-Emissionen aus Korrosionsschutz-Sannierungen in der Schweiz - 1 Emissionsfaktoren, 2 Emissionen 1900-2015' Büro für Abfall, Seewen. Auftraggeber: BUWAL Abteilung Luftreinhaltung, Umweltschutzfachstellen der Kantone Glarus, Graubünden, Luzern, Schwyz, Wallis und Zürich, Seewen, Schweiz. 
Stolz, J., Lehmann, P., Heim, T., Keller, J. and Leuenberger, H.: 1994, 'Sanierung korrosionsgeschützter Stahlobjekte im Freien - Umweltbelastungen und Minderungsmassnahmen', Carbotech AG, Auftraggeber: Ämter für Umweltschutz der Kantone Glarus, Graubünden und Zürich, Basel, Switzerland.

Tidblad, J., Mikhailov, A. A. and Kucera, V.: 1999, 'Unified dose-response functions after 8 Years of exposure', in S. Fitz (ed), UN/ECE Workshop on Quantification of Effects of Air pollutants on Materials, Berlin, May, pp. 77-86.

Verbiest, P., Waeterschoot, H., Racek, R. and Leclercq, M.: 1997, 'Zinc and the environment - a study of runoff and corrosion rates of rolled zinc sheet in different exposures', Prot. Coat. Europe 2(9), $47-58$. 


$$
-1
$$

